\title{
Enhanced serum oestrogen levels and highly steroidogenic, luteinized atretic follicles in the ovaries of the Djungarian hamster (Phodopus sungorus) kept under a short photoperiod from birth
}

\author{
R van den Hurk, G Dijkstra and F H de Jong ${ }^{1}$ \\ Department of Farm Animal Health, Veterinary Faculty, Utrecht University, Yalelaan 7, PO Box 80151, 3508 TD Utrecht, The Netherlands and \\ ${ }^{1}$ Department of Endocrinology and Reproduction, Erasmus University Rotterdam, PO Box 1738, 3000 DR Rotterdam, The Netherlands \\ (Correspondence should be addressed to R van den Hurk; Email: r.vandenhurk@vet.uu.nl)
}

\begin{abstract}
Objective: In contrast to the elaborate information available on the effects of the photoperiod on the testes of hamsters, little is known about the influence on their ovaries. This study aimed to describe the ovarian follicular development and steroid hormone production in Djungarian hamsters kept from birth under a short daylight regime.

Design and Methods: Female Djungarian hamsters (Phodopus sungorus) were kept under two different light regimes: (i) $16 \mathrm{~h}$ light: $8 \mathrm{~h}$ darkness (long daylight; LD) and (ii) $4 \mathrm{~h}$ light:20 h darkness (short daylight; SD). They were killed at 28, 56 and 80 days after birth; blood and ovaries were collected. Ovaries were either fixed in Bouin's solution or frozen. Fixed material was dehydrated, embedded in paraffin, serially sectioned at $5 \mu \mathrm{m}$ and stained with haematoxylin and eosin, whereafter all

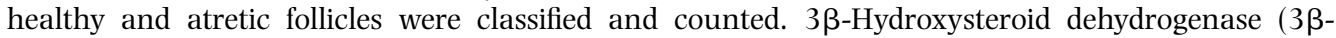
HSD) was histochemically demonstrated in $10 \mu \mathrm{m}$ sections of frozen ovaries. Serum oestradiol-17 $\beta$ and progesterone levels were determined by RIA.

Results: The numbers of healthy preantral and antral follicles were higher in LD than in SD hamsters. Antral follicles did not significantly differ in number during development in LD hamsters, but they were completely absent from 80-day-old SD animals. In LD animals the number of apoptotic preantral follicles dramatically increased with age. In SD animals the numbers of apoptotic antral follicles strongly decreased with age, whereas numerous non-apoptotic follicles with luteinized granulosa cells and a degenerated oocyte appeared, and in increasing numbers with age. During development, moderate $3 \beta$-HSD activity was present in interstitial cells, theca cells of healthy follicles, and in both theca and granulosa cells of degenerating follicles. Strong enzyme activity was found in the hypertrophied granulosa cells of luteinized atretic follicles. Mean serum progesterone values varied from 2 to $6 \mathrm{nmol} / \mathrm{l}$ and were not different in LD and SD hamsters. Mean serum oestradiol levels varied from 132 to 542 and 325 to $2353 \mathrm{pmol} / \mathrm{l}$ in LD and SD hamsters respectively. The highest oestradiol levels were found in SD animals at day 28 of development.

Conclusions: Folliculogenesis was dramatically disturbed in Djungarian hamsters raised under a short photoperiod. These animals developed high serum oestradiol levels and numerous luteinized atretic follicles with highly steroidogenic granulosa cells, which appear to be the source of the increased serum oestradiol levels.
\end{abstract}

European Journal of Endocrinology 147 701-710

\section{Introduction}

In many seasonally breeding rodent species reproductive activity is influenced by daylength. In these animals short photoperiods evoke a delay but do not prevent gonadal development (1-3). In immature Djungarian hamsters short photoperiods hamper gonadal growth in prepubertal male $(4,5)$ and female $(6)$ animals for months. There is strong evidence that in Djungarian hamsters, as in other rodents (7), the daily temporal pattern of synthesis and release of melatonin by the epiphysis may be involved in transforming photoperiodic information $(8,9)$, i.e. from 10 days of age onwards when the neural photoperiodic transduction system is well established (10). Melatonin is generally considered to have an anti-gonadotrophic action on the pituitary (11-13). Indeed, in the male Djungarian hamster, a short photoperiod has been shown to block 
peak follicle-stimulating hormone (FSH) secretion and to suppress serum luteinizing hormone (LH) and androgen production (14). While the influence of daylength on the testes in Djungarian hamsters has been extensively studied $(5,15)$, little detailed information concerning the effects of photoperiod on ovarian processes has been reported in this species. The present paper describes ovarian follicular development and steroid hormone production of Djungarian hamsters kept from birth under short ( $4 \mathrm{~h}$ light: $20 \mathrm{~h}$ darkness) and control long ( $16 \mathrm{~h}$ light: $8 \mathrm{~h}$ darkness) photoperiodic conditions. The localization and activity of ovarian $3 \beta-$ hydroxysteroid dehydrogenase ( $3 \beta-\mathrm{HSD})$, a key enzyme in steroid biosynthesis, and serum progesterone and oestradiol-17 $\beta$ levels were determined.

\section{Materials and methods}

\section{Animals and experimental design}

Djungarian hamsters (Phodopus sungorus) were born in our laboratory breeding colony (supplied by P Niklowitz, Max Planck Clinical Research Unit for Reproductive Medicine, Munster, Germany). Two different light regimens were used: (i) $16 \mathrm{~h}$ light: $8 \mathrm{~h}$ darkness (lights were on from 0200 to $1800 \mathrm{~h}$ ) before and after birth (LD) and (ii) $16 \mathrm{~h}$ light: $8 \mathrm{~h}$ darkness before birth and $4 \mathrm{~h}$ light: $20 \mathrm{~h}$ darkness (lights were on from 1300 to $1700 \mathrm{~h}$ ) after birth (SD). Pups were weaned at 3 weeks of age. In control LD animals, first ovulations were observed at the age of about 64 days. To obtain data on follicular development, hamsters aged 28, 56 and 80 days were killed by decapitation. Each group consisted of animals from different litters. Body and ovarian weights were measured and trunk blood was collected to determine oestradiol and progesterone concentrations by radioimmunoassay (RIA). Blood samples were allowed to clot overnight at $4{ }^{\circ} \mathrm{C}$, centrifuged and the serum was stored at $-20^{\circ} \mathrm{C}$ until assayed.

\section{Morphological analysis}

For morphological studies, hamster $(n=6-13$ per group) ovaries were fixed in Bouin's solution, dehydrated, embedded in paraffin (Paraclean), serially sectioned at $5 \mu \mathrm{m}$ and every fifth cross-section was stained with the periodic acid-Schiff (PAS) technique and haematoxylin. In every stained cross-section all healthy and atretic follicles were examined and counted to obtain an approximate estimation of their numbers. To avoid double counting of healthy and atretic follicles, only those that showed the nucleus of the oocyte were counted and in the antral class the follicles were compared with previous sections. Corpora lutea, which are in fact post-antral follicles, were counted in the same way as the follicles in the antral class. In the case of atretic follicles, only those that showed at least part of the oocyte or a collapsed zona pellucida were counted. Healthy follicles were classified as: (i) early preantral follicles with one or two layers of cuboidal granulosa cells, (ii) advanced preantral follicles with three or more layers of granulosa cells, (iii) antral follicles with many layers of granulosa cells with either scattered areas containing fluid or a single cavity of fluid, and (iv) corpora lutea. Atretic follicles were classified as: (i) apoptotic preantral follicles with an intact oocyte, but with condensed or fragmented granulosa cell nuclei and with or without disorganized hypertrophied granulosa cells, (ii) apoptotic antral follicles with generally an intact oocyte and with condensed or fragmented granulosa cell nuclei together with disorganized layers of pyknotic and/or hypertrophied granulosa cells, and (iii) luteinized atretic follicles (LAFs) consisting of a degenerating oocyte and/or a collapsed zona pellucida, a granulosa with a compact mass of non-proliferating, hypertrophied cells, which resemble the lutein cells of corpora lutea, and a theca of which most cells have a round nucleus.

\section{Enzyme histochemistry}

$3 \beta$-HSD was demonstrated in $10 \mu \mathrm{m}$ sections of hamster ( $n=5$ per group) ovaries that were quickly

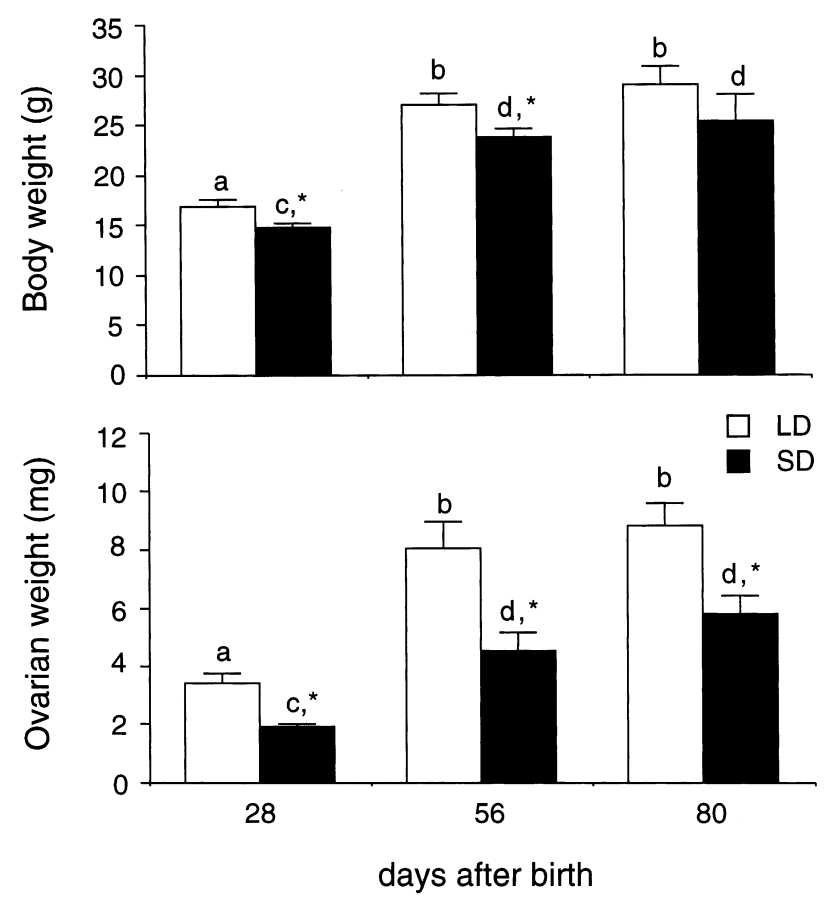

Figure 1 Mean \pm S.E.M. body weight and mean ovarian weight of Djungarian hamsters kept under SD and LD light regimens from birth $(n=6-13)$. Data were tested with two-way univariate ANOVA and differences were considered significant when $P<0.05$ : *significant difference between LD and SD animals of the same age; ${ }^{a, b}$ significant difference between LD animals of different ages; ${ }^{c, d}$ significant difference between SD animals of different ages. 

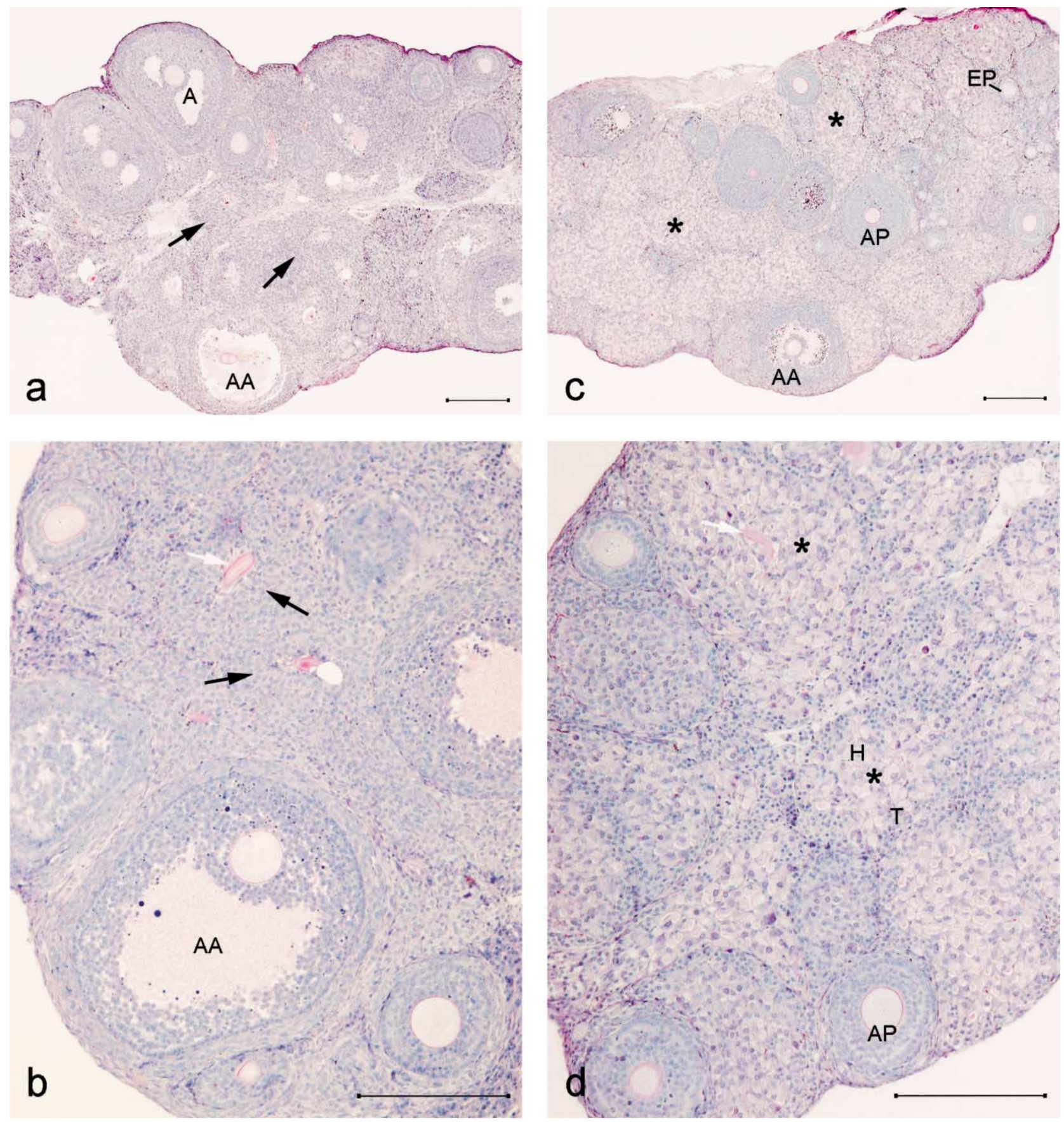

Figure 2 PAS-haematoxylin-stained sections of Djungarian hamster ovaries. (a,b) Ovary of a 56-day-old hamster, kept under LD from birth, with many apoptotic follicles eventually leading to masses of theca cells (black arrows). (c,d) Ovary of a 56-day-old hamster, kept under SD from birth, with numerous LAFs (asterisks). EP, early preantral follicle; AP, advanced preantral follicle; AA, apoptotic antral follicle; $\mathrm{H}$, hypertrophied granulosa cells of a LAF; T, theca cells of a LAF; white arrows, collapsed zona pellucida. Bars, $200 \mu \mathrm{m}$.

frozen with $\mathrm{CO}_{2}$ and cut with a cryostat microtome at $-25^{\circ} \mathrm{C}$ and according to the method of van den Hurk (16). Briefly, sections pretreated for 2 min with xylene were incubated for $3 \mathrm{~h}$ at $37^{\circ} \mathrm{C}$ in a $0.1 \mathrm{M}$ phosphate buffer medium ( $\mathrm{pH}$ 8.3) to which nicotinamide-adenine dinucleotide (NAD) $(2 \mathrm{mg} / \mathrm{ml}$;
Roche Diagnostics, Mannheim, Germany), nitro blue tetrazolium salt $(0.5 \mathrm{mg} / \mathrm{ml}$; Sigma, Steinheim, Germany) and dehydroepiandrosterone $(0.2 \mathrm{mg} / \mathrm{ml}$; Merck, Darmstadt, Germany), dissolved in $0.5 \mathrm{ml}$ dimethyl formamide (Merck) were added. The specificity of the reaction was confirmed by omission of the 
substrate or NAD in the reaction medium. Hamster liver tissue was used as a negative control.

\section{Radioimmunoassays}

Serum oestradiol concentrations were estimated in hamsters ( $n=7$ per group) using a coated-tube RIA purchased from Diagnostic Products Corporation (Los Angeles, CA, USA). Serum progesterone concentrations were measured ( $n=7$ per group) by RIA according to the method described by de Jong et al. (17). The sensivity of the oestradiol assay was $37 \mathrm{fmol} /$ tube and the intra- and interassay variations were 7.2 and $8.3 \%$ respectively. The sensivity of the progesterone assay was $80 \mathrm{fmol} /$ tube, and the intra- and interassay variations were 13.7 and $16 \%$ respectively.

\section{Statistical analysis}

Results are expressed as means \pm S.E.M. All data were tested with two-way univariate ANOVA. Differences were considered significant when $P<0.05$.

\section{Results}

Mean body and ovarian (Fig. 1) weights of SD and control LD hamsters had increased at day 56 when compared with day 28. From this point their growth flattened. SD hamsters showed significantly lower ovarian weight than $\mathrm{LD}$ hamsters, while their body weights were not different.

The ovaries of Djungarian hamsters kept under LD were characterized by the presence of various types of follicles, many of which showed apoptotic degeneration of their granulosa cells, eventually leading to thecal cell masses that may contain a wrinkled zona pellucida (Figs. 2a,b and 3a). In contrast, the ovaries of hamsters kept under SD circumstances were characterized by the presence of LAFs (Fig. 2c,d). Compared with corpora lutea (Fig. 3c,d), LAFs are generally three to four times smaller, while their hypertrophied granulosa cells remain surrounded by theca cells (Figs. $2 \mathrm{~d}$ and $3 b)$. Corpora lutea were only observed in 80-day-old LD hamsters (Table 1). They were characterized by the presence of large numbers of lutein cells and were highly vascularized (Fig. 3d). Compared with LD animals, those kept under SD had significantly more early preantral follicles at day 28 and less advanced preantral follicles at day 56 (Table 1). Ovaries of 28day-old SD animals contained more advanced preantral follicles than those of older hamsters, while the numbers of these follicles did not vary with age in LD hamsters. At all ages studied, the numbers of early preantral follicles remained constant during development in both SD and LD animals. The numbers of healthy antral follicles were higher in LD than in SD hamsters. During aging, the numbers of these follicles did not significantly differ in LD hamsters, but they were completely absent in 80-day-old SD animals. In contrast to SD hamsters, the number of apoptotic preantral follicles in LD animals dramatically increased with age, while the number of apoptotic antral follicles strongly decreased in the SD hamsters (Table 1). Instead, LAFs appeared in SD animals; large numbers being present at day 56 and day 80 after birth (Table 1).

During development, moderate $3 \beta$-HSD activity was present in interstitial cells (Fig. 4a,c,d), in theca cells of healthy follicles (Fig. 4a-d), apoptotic follicles (Fig. 4a,b) and LAFs (Fig. 4c,d), and in granulosa cells of apoptotic follicles (Fig. 4a,b). Strong enzyme activity was present in hypertrophied granulosa cells of apoptotic follicles and LAFs, the latter structures being the most reactive (Fig. 4c,d). 3 $\beta$-HSD reactions were negative in liver tissue (Fig. 4a) and when the substrate or NAD was omitted from the reaction medium (Fig. 4e).

Mean serum progesterone values varied from 2.6 to $6.6 \mathrm{nmol} / \mathrm{l}$. The progesterone profiles in $\mathrm{LD}$ animals were not different from those kept under an SD light regimen, the concentrations being lowest at day 28 (Fig. 5). Mean serum oestrogen levels varied from 124 to $2356 \mathrm{pmol} / \mathrm{l}$. The oestrogen levels were significantly higher in SD animals than in LD hamsters, and the highest values were found at day 28 after birth, especially in the SD group (Fig. 5).

\section{Discussion}

Control LD hamsters showed normal follicular development eventually leading to ovulation and its attendant apoptotic degeneration of many preantral and antral follicles. Corpora lutea were only seen in 80-day-old control animals and not in those of 56 days, which contrasts with the previous findings of Theuring \& Hansmann (18). Serum progesterone and oestradiol levels in the present control animals were within the range of those previously described for samples from this species $(19,20)$.

SD conditions from birth onwards had no effect on the body growth of Djungarian hamsters, but negatively influenced the development of their ovaries as reflected by lower ovarian weights and disturbed folliculogenesis. These ovaries contained fewer healthy preantral and antral follicles, less apoptotic preantral and antral follicles and more LAFs than those of LD animals, while corpora lutea were not formed. Ebling (6) previously described severe inhibition of gonadal and body growth in immature Djungarian hamsters raised under short days. Short photoperiod also attenuated body growth in adult Djungarian hamsters, but had no significant effect on ovarian weight $(21,22)$; the gonads of these animals contained fewer healthy antral follicles and corpora lutea and more apoptotic antral follicles (21). The different effects of a short daylight regimen on 

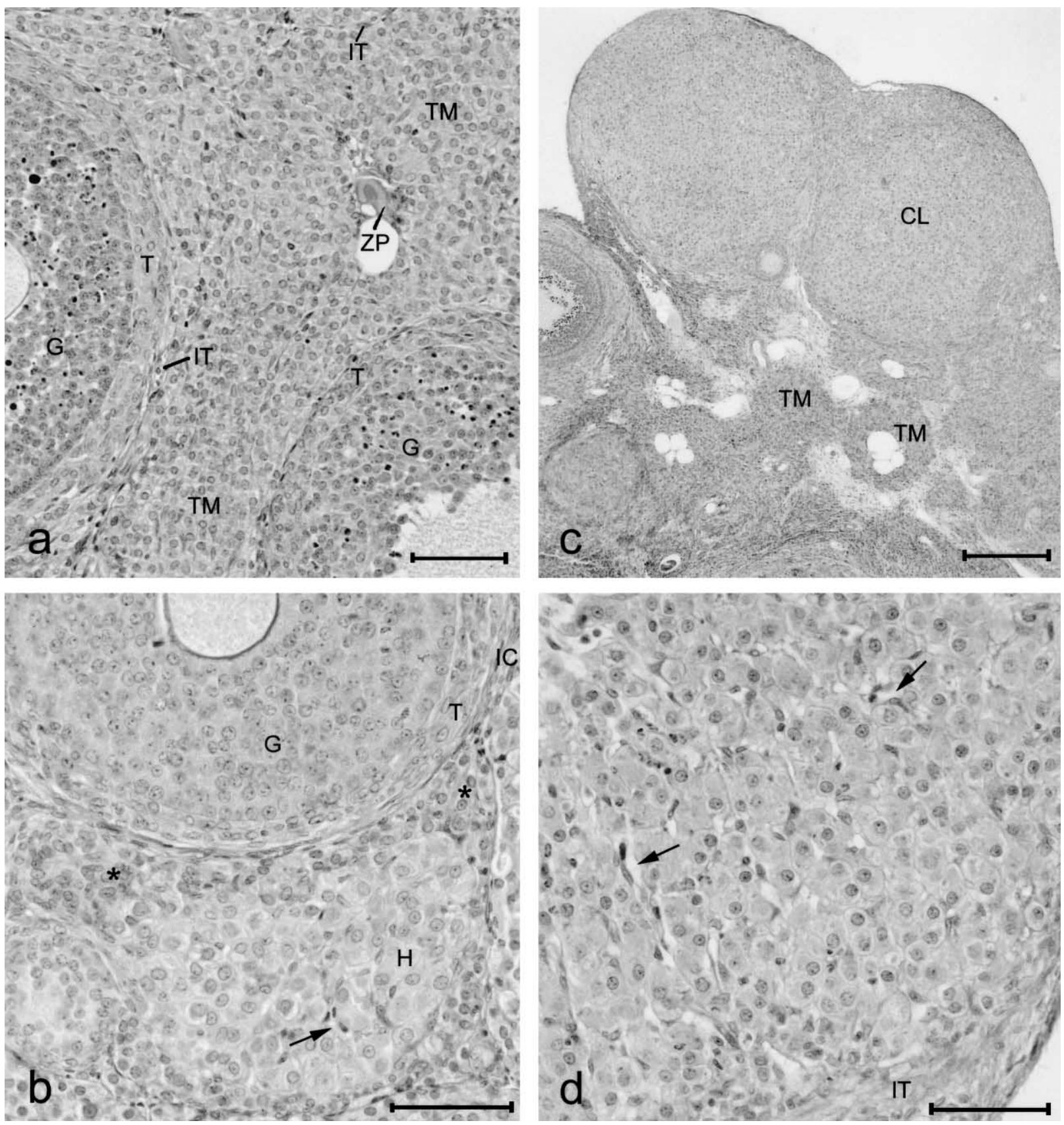

Figure 3 PAS-haematoxylin-stained sections of Djungarian hamster ovaries. (a) Detail of an ovary of a 56-day-old LD hamster showing theca cell masses (TM) and the granulosa (G) and theca (T) of two apoptotic follicles. IT, interstitial tissue. Bar, $50 \mu \mathrm{m}$. (b) Detail of an ovary of a 56-day-old SD hamster showing a luteinized atretic follicle, consisting of hypertrophied granulosa cells $(H)$ surrounded by theca cells (asterisks). Note that most theca cells have a round nucleus. Furthermore, the granulosa $(G)$ and theca $(T)$ of an advanced preantral follicle is visible. Bar, $50 \mu \mathrm{m}$. (c) Ovary of a 80-day-old LD hamster, characterized by the presence of corpora lutea (CL) and theca cell masses (TM). Bar, $200 \mu \mathrm{m}$. (d) Detail of a well-vascularized corpus luteum, showing numerous hypertrophied cells. Bar, $50 \mu \mathrm{m}$. IC, interstitial tissue; arrows, capillaries; ZP, collapsed zona pellucida.

immature and adult hamsters can be attributed to differences in the functioning of the neuroendocrine reproductive system. In immature animals, the whole system transducing the photoperiodic information via the epiphysis to the hypothalamus-pituitary-ovarian axis leading to adequate output of gonadotrophins and steroid hormones has still to be fully constructed (10, $23,24)$, whereas, in adult specimens, cyclic activity has already been triggered by well-functioning extraovarian and intraovarian hormonal systems (25-28).

A striking finding in our studies is the formation of numerous non-apoptotic atretic follicles with luteinized 
Table 1 The number of the various types of healthy follicles, atretic follicles and corpora lutea (CL) per Djungarian hamster kept under $\mathrm{SD}$ or LD light regimens. Values are expressed as means \pm S.E.M.

\begin{tabular}{|c|c|c|c|c|c|c|c|c|}
\hline \multirow[b]{2}{*}{ Animals } & \multirow[b]{2}{*}{$n$} & \multicolumn{3}{|c|}{ Healthy follicles } & \multirow[b]{2}{*}{ CL } & \multicolumn{3}{|c|}{ Atretic follicles } \\
\hline & & EAPF & ADPF & ANF & & APF & AAF & LAF \\
\hline \multicolumn{9}{|l|}{ LD } \\
\hline 28 days & 10 & $52 \pm 4.4^{x}$ & $55 \pm 4.4$ & $6 \pm 0.9^{x}$ & $0 \pm 0.0$ & $74 \pm 5.6^{\mathrm{a}}$ & $19 \pm 3.3$ & $0 \pm 0.0^{x}$ \\
\hline 56 days & 13 & $70 \pm 7.1$ & $45 \pm 3.8^{x}$ & $7 \pm 1.0^{x}$ & $0 \pm 0.0$ & $261 \pm 14.5^{\mathrm{xb}}$ & $22 \pm 2.5^{x}$ & $0 \pm 0.0^{x}$ \\
\hline 80 days & 12 & $71 \pm 16.0$ & $48 \pm 8.5$ & $5 \pm 1.4^{x}$ & $3 \pm 1.7$ & $405 \pm 42.0^{\mathrm{xc}}$ & $16 \pm 1.5^{x}$ & $2 \pm 1.5^{x}$ \\
\hline \multicolumn{9}{|l|}{ SD } \\
\hline 28 days & 7 & $96 \pm 5.4^{y}$ & $66 \pm 4.3^{d}$ & $2 \pm 0.8^{y d}$ & $0 \pm 0.0$ & $63 \pm 13.7^{d}$ & $17 \pm 4.2^{d}$ & $17 \pm 5.2^{y d}$ \\
\hline 56 days & 6 & $71 \pm 11.8$ & $26 \pm 4.3^{\mathrm{ye}}$ & $1 \pm 0.4^{\text {yde }}$ & $0 \pm 0.0$ & $15 \pm 2.9^{\mathrm{ye}}$ & $4 \pm 0.6^{\mathrm{ye}}$ & $116 \pm 16.6^{\mathrm{ye}}$ \\
\hline 80 days & 6 & $89 \pm 16.5$ & $31 \pm 5.6^{\mathrm{e}}$ & $0 \pm 0.0^{\mathrm{ye}}$ & $0 \pm 0.0$ & $33 \pm 5.4^{\mathrm{yde}}$ & $1 \pm 0.4^{\mathrm{ye}}$ & $125 \pm 40.0^{\mathrm{ye}}$ \\
\hline
\end{tabular}

EAPF, early preantral follicles; ADPF, advanced preantral follicles; ANF, antral follicles; APF, apoptotic preantral follicles; AAF, apoptotic antral follicles; $\mathrm{LAF}$, luteinized atretic follicles.

$P<0.05:^{\mathrm{x}, \mathrm{y}}$ comparison between LD and SD animals of the same age; ${ }^{\mathrm{a}, \mathrm{b}, \mathrm{c}}$ comparison between LD animals of different ages; ${ }^{\mathrm{d}, \mathrm{e}}$ comparison between SD animals of different ages (two-way univariate ANOVA).

granulosa cells (LAFs) in SD hamsters. Similar lutein structures were previously described as atretic preantrum follicles (29) or corpora lutea accessoria (30), and are occasionally found in many species, including hamsters (31). Their morphology resembles that of luteinized unruptured follicles $(32,33)$ and of corpora lutea, structures that are both derived from antral follicles. However, as in the hamsters studied by Knigge \& Leathem (29), this type of degeneration in SD Djungarian hamsters seems to be restricted to preantral follicular stages, since LAFs lack an antrum and their size does not exceed that of preantral follicles. Similar luteinized follicular structures also appear in growth differentiation factor-9 (GDF-9)-deficient mice (34) and in various other mammalian species, for example after treatment with exogenous hormones or by grafting the ovary under the kidney capsule or cornea $(35,36)$. These findings and the present data confirm the suggestion of El-Fouly et al. (37) that granulosa cells automatically luteinize after removal or degeneration of the oocyte, indicating that the oocyte produces a luteinizing suppressing agent. The decision of the follicle to undergo atresia, starting with the degeneration of the oocyte or with apoptosis of the granulosa cells, is probably related to its stage of development and its previous stimulation by gonadotrophins (38). This might explain the absence of LAFs in the studies of Schlatt et al. (21) with ovaries of adult hamsters kept under short days.

In this study, $3 \beta$-HSD, a key enzyme in steroid biosynthesis, was demonstrated in theca cells of healthy and atretic follicles, granulosa cells of atretic follicles and interstitial cells. These findings correspond with those of other studies dealing with the localization of steroid formation in rodent ovaries (39-45). The most intensive expression of this key enzyme in steroid biosynthesis was detected in the hypertrophied granulosa cells of degenerating follicles, the LAFs being the most reactive structures. Apart from the numerous highly steroidogenic LAFs, SD hamsters had high serum oestradiol levels, while the progesterone values did not deviate from those kept under a long photoperiod. These observations support the idea that LAFs are responsible for the high oestradiol levels. The oestrogenic potency of these lutein structures corresponds with that of the lutein cells of hamster $(46,47)$ and rat $(48,49)$ corpora lutea and of the luteinized follicular nests of GDF-9-deficient mouse ovaries (34), and it is in sharp contrast to the rapid decline and eventual shut off of oestrogen synthesis in apoptotic follicles, due, among other reasons, to the poor expression and lack of aromatase activity respectively $(25,47,50-$ 52 ). The relatively high serum oestrogen levels and the strong steroidogenic activity in the ovaries of SD hamsters is remarkable, in view of the expected prolonged daily circulation of the anti-gonadotrophin melatonin $(9,22)$ and lower FSH and LH levels (14). The disappearance of a functional oocyte in LAFs, and therefore of an inhibiting factor, is possibly the cause of their increased steroid-synthesizing capacity, by which, even in circumstances of low gonadotrophin secretion, oestrogen formation is permitted. GDF-9 might be such an oocyte-derived factor that suppresses luteinization and the accompanying steroid formation (34).

Although serum oestrogen levels stay relatively high, they decline with increasing age in the Djungarian hamsters, while the number of LAFs increase. This might be due to the declining activity of enzymes, such as aromatase and $17 \alpha$-hydroxylase, which are involved in the formation of this oestrogen. Perhaps the initial high oestradiol concentrations together with the continuing SD circumstances have a negative effect on the output of gonadotrophins by the pituitary, which leads to minimal serum concentrations of LH and/or FSH, hormones that are necessary to maintain the formation of thecal androgens and granulosa oestrogens respectively $(53,54)$. Alternatively, the high oestradiol concentrations might influence the local intraovarian control system that regulates the synthesis 

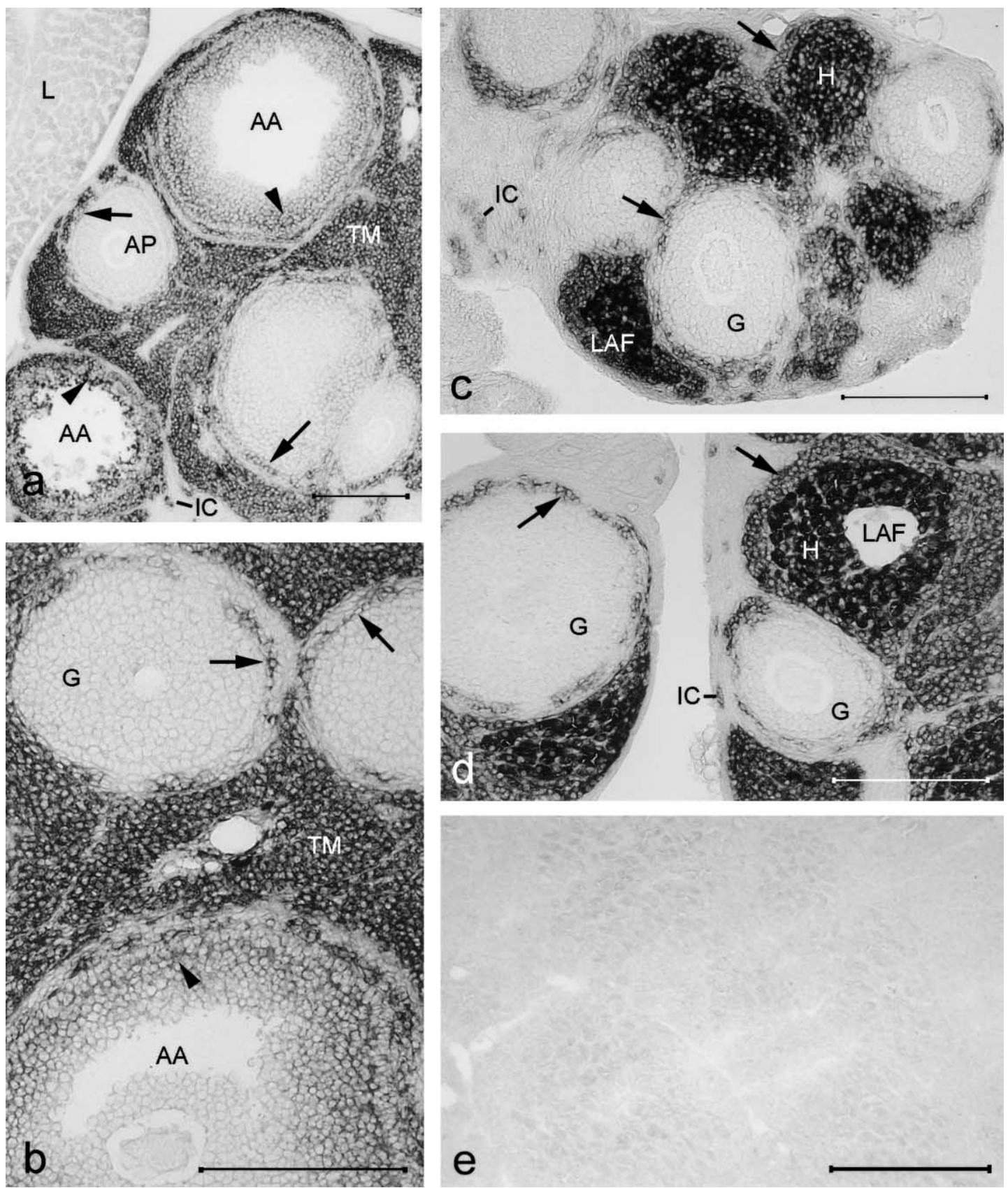

Figure 4 Localization of $3 \beta$-HSD activity in Djungarian hamster ovaries. (a,b) Ovaries of 28-day-old hamsters, kept under LD from birth, with $3 \beta-H S D$ activity in follicular theca cells (arrows), in theca cell masses (TM) being the remnants of apoptotic follicles, interstitial cells (IC) and granulosa cells of degenerating follicles (arrowheads). Note the absence of enzyme activity in the liver (L). (c,d) Ovaries of hamsters kept under SD from birth for 28 and 56 days respectively, with strong $3 \beta-H S D$ activity in the hypertrophied granulosa cells $(H)$ of LAFs and lesser enzyme activity in theca cells of these and other types of follicles (arrows) and in interstitial cells (IC). (e) Absence of $3 \beta$-HSD staining in the ovary of a 56-day-old SD hamster after omission of the substrate from the reaction medium. Bars, $200 \mu \mathrm{m}$; AP, advanced preantral follicle; G, granulosa of advanced preantral follicle; AA, apoptotic antral follicle.

of oestrogens. Apparently, the gonadotrophin levels remain sufficiently high to maintain $3 \beta-\mathrm{HSD}$ activity and thus progesterone production at these sites. Unfortunately, we were not able to collect sufficient amounts of blood to measure serum gonadotrophin in addition to steroid levels.
In neonatal mammalian ovaries, oestradiol is one of the many factors that rescue follicles from undergoing atresia by apoptosis and stimulate follicular development by cell proliferation (55-59). In this respect, the concentration of locally produced oestradiol and the numbers of oestradiol receptors are important 

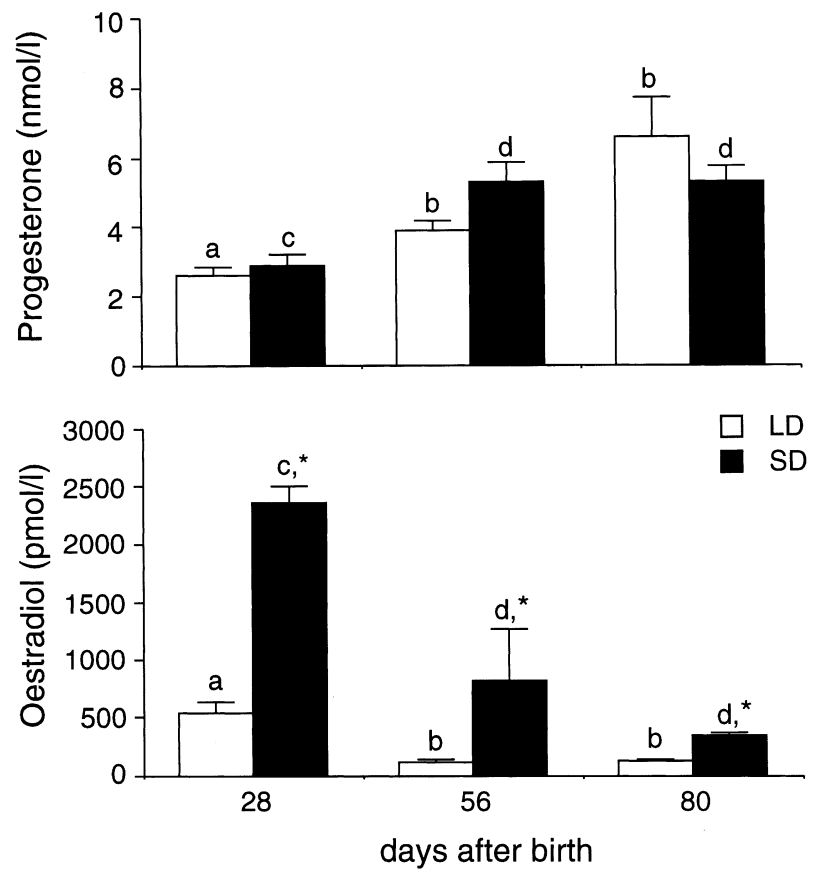

Figure 5 Mean \pm S.E.M. serum progesterone $(\mathrm{nmol} / \mathrm{l})$ and oestradiol (pmol/l) levels in Djungarian hamsters $(n=7)$ kept under a SD or LD light regimen. Data were tested with two-way univariate ANOVA and differences were considered significant when $P<0.05$ : *significant difference between LD and SD animals of the same age; ${ }^{a, b}$ significant difference between LD animals of different ages; ${ }^{c, d}$ significant difference between SD animals of different ages.

$(38,57,60,61)$. The absence of mitotic granulosa cells in the LAFs of SD hamsters might point to the absence of adequate numbers of oestradiol receptors, since there is no shortage of local oestrogen. Formation of oestrogen receptors is regulated by gonadotrophins and steroids such as oestradiol itself $(38,60,62)$. Consequently, the aberrant concentrations of FSH, LH (14) and oestradiol (this paper) in SD hamsters may have negatively affected the expression of oestrogen receptors in the granulosa cells, and thus their mitotic capacity. During the period of investigation, the granulosa cells of LAFs not only fail to proliferate but also fail to die, as apoptotically degenerating follicles commonly do. Apparently, as in the lutein structures of GDF-9deficient ovaries (34), these LAFs lack an oocytederived factor that allows follicles to acquire the capability to undergo apoptosis.

In summary, exposing female Djungarian hamsters from birth to an SD photoperiod leads to retardation of ovarian growth and disturbance of ovarian folliculogenesis and steroidogenesis. Most evident is the formation of highly steroidogenic LAFs in the presence of high serum oestradiol levels, indicating the LAFs as the source of this oestrogen. The increased oestradiol formation is not able to stimulate proliferation of the granulosa cells in LAFs but, as in corpora lutea, is associated with the luteinization of their granulosa cells. As in corpora lutea, granulosa oestrogen synthesis and luteinization in LAFs is initiated after the disappearance of the oocyte, which is in support of a luteinizing suppressing role of follicle-enclosed oocytes. Future studies with SD Djungarian hamsters on serum gonadotrophin levels and the formation of follicular oestradiol, oestradiol receptors and other markers for granulosa cell luteinization may give more conclusive evidence for the mechanisms involved in the development of LAFs.

\section{Acknowledgements}

We are grateful to Dr E G Dingboom for statistical analysis and to Mr F Kindt and Mr R Leito for making the photographs.

\section{References}

1 Breed WG \& Clarke JR. Effect of photoperiod on ovarian function in the vole, Microtus agrestis. Journal of Reproduction and Fertility $197023189-192$.

2 Johnston PG \& Zucker I. Photoperiodic regulation of reproductive development in white-footed mice (Peromyscus leucopus). Biology of Reproduction 198022 983-989.

3 Hong SM \& Stetson MH. Functional maturation of the gonads of Turkish hamsters under various photoperiods. Biology of Reproduction $198635858-862$.

4 Brakmann M \& Hoffmann K. Pinealectomy and photoperiod influence testicular development in the Djungarian hamster. Naturwissenschaften $197764341-342$.

5 Hoffmann K. Effects of short photoperiods on puberty, growth and moult in the Djungarian hamster (Phodopus sungorus). Journal of Reproduction and Fertility $1978 \mathbf{5 4} 29-35$.

6 Ebling FJ. Photoperiodic differences during development in the dwarf hamsters Phodopus sungorus and Phodopus campbelli. General and Comparative Endocrinology 199495 475-482.

7 Yellon SM, Tamarkin L, Pratt BL \& Goldman BD. Pineal melatonin in the Djungarian hamster: photoperiodic regulation of a circadian rhythm. Endocrinology $1982111488-492$.

8 Goldman BD \& Darrow JM. The pineal gland and mammalian photoperiodism. Neuroendocrinology 198337 386-396.

9 Hoffmann K \& Illnerova H. Photoperiodic effects in the Djungarian hamster. Neuroendocrinology 198643 317-321.

10 van Veen T, Brackmann M \& Moghimzadeh E. Postnatal development of the pineal organ in the hamsters Phodopus sungorus and Mesocricetus auratus. Cell and Tissue Research 1978189 $241-250$.

11 Reiter RJ, Sorrentino S \& Hoffmann RA. Early photoperiodic conditions and pineal antigonadal function in male hamsters. International Journal of Fertility 197015 163-170.

12 Turek FW. Photoperiodic regulation of neuroendocrine-gonadal activity. Biology of Reproduction $19792032-50$.

13 Leskowitz E. Seasonal affective disorder and the yoga paradigm: a reconsideration of the role of the pineal gland. Medical Hypotheses 199033 155-158.

14 Yellon SM \& Goldman BD. Photoperiod control of reproductive development in the male Djungarian hamster (Phodopus sungorus). Endocrinology $1984114664-670$.

15 van Haaster, L. Regulation of Postnatal Testicular Development in Rodents Thesis University of Utrecht, The Netherlands.

16 van den Hurk R. Localization of steroidogenesis in the testes of oviparous and viviparous teleosts. Koninklijke Nederlandse Akademie van Wetenschappen 197376 (Series C) 270-279. 
17 de Jong FH, Baird DT \& van der Molen HJ. Ovarian secretion rates of oestrogens, androgens and progesterone in normal women and in women with persistent ovarian follicles. Acta Endocrinologica $197477575-587$.

18 Theuring F \& Hansmann I. Follicular development in immature Djungarian hamsters (Phodopus sungorus) and the influence of exogenous gonadotropins. Biology of Reproduction 198635 407-412.

19 Wynne-Edwards KE, Terranova PF \& Lisk RD. Cyclic Djungarian hamsters, Phodopus campbelli, lack the progesterone surge normally associated with ovulation and behavioral receptivity. Endocrinology $1987 \mathbf{1 2 0} 1308-1316$.

20 Reburn CJ \& Wynne-Edwards KE. Novel patterns of progesterone and prolactin in plasma during the estrous cycle in the Djungarian hamster (Phodopus campbelli) as determined by repeated sampling of individual females. Biology of Reproduction $1996 \mathbf{5 4}$ 819-825.

21 Schlatt S, Niklowitz P, Hoffmann K \& Nieschlag E. Influence of short photoperiods on reproductive organs and estrous cycles of normal and pinealectomized female Djungarian hamsters, Phodopus sungorus. Biology of Reproduction $199349243-250$.

22 Lerchl A \& Schlatt S. Influence of photoperiod on pineal melatonin synthesis, full color, body weight, and reproductive function in the female Djungarian hamster, Phodopus sungorus. Neuroendocrinology $199357359-364$.

23 Dissen GA, Les Dee W \& Ojeda SR. Neural and neurotrophic control of ovarian development. In The Ovary, pp 1-19. Eds EY Adashi \& PCK Leung. New York: Raven Press, 1993.

24 Ebling FJ \& Cronin AS. The neurobiology of reproductive development. Neuroreport 200011 R23-R33.

25 Fortune JE. Ovarian follicular growth and development in mammals. Biology of Reproduction $199450225-232$.

26 van den Hurk R, Bevers MM \& Beckers JF. In-vivo and in-vitro development of preantral follicles. Theriogenology $1997 \mathbf{4 7}$ $73-82$.

27 van den Hurk R, Abir R, Telfer EE \& Bevers MM. Primate and bovine immature oocytes and follicles as sources of fertilizable oocytes. Human Reproduction Update 20006 457-474.

28 McGhee EA \& Hsueh AJ. Initial and cyclic recruitment of ovarian follicles. Endocrine Reviews $200021200-214$.

29 Knigge KM \& Leathem JH. Growth and atresia of follicles in the ovary of the hamster. Anatomical Record $1956 \mathbf{1 2 4} 679-708$.

30 Weir BJ \& Rowlands IW. Ovulation and atresia. In The Ovary, pp 265-301. Eds L Zuckerman \& BJ Weir. New York: Academic Press, 1977.

31 Harrison RJ \& Weir BJ. Structure of the mammalian ovary. In The Ovary, pp 113-217. Eds I Zuckerrman \& BJ Weir. New York: Academic Press, 1977.

32 Kuryszko J \& Adamski RT. Luteinization in the atresia of maturing ovarian follicles in mouse. Zeitschrift für Mikroskopische und Anatomische Forschung $1990 \mathbf{1 0 4}$ 515-520.

33 Mattheij JA \& Swarts HJ. Induction of luteinized unruptured follicles in the rat after injection of luteinizing hormone early in pro-oestrus. European Journal of Endocrinology 1995132 91-96.

34 Elvin JA, Yan C, Wang P, Nishimori K \& Matzuk MM. Molecular characterization of the follicle defects in the growth differentiation factor 9-deficient ovary. Molecular Endocrinology $1999131018-$ 1034.

35 Welschen R. Corpora lutea atretica in ovarian grafts. Journal of Endocrinology $197149693-694$.

36 Jones EE \& Nalbandov AV. Effects of intrafollicular injection of gonadotropins on ovulation and luteinization of ovarian follicles. Biology of Reproduction 19727 87-83.

37 El-Fouly MA, Cook B, Nekola M \& Nalbandov AV. The role of the ovum in follicular luteinization. Endocrinology $1970 \mathbf{8 7}$ 288-293.

38 Richards JS. Estradiol receptor content in rat granulosa cells during follicular development: modification by estradiol and gonadotropins. Endocrinology $1975971174-1184$.
39 Baillie AH, Ferguson MM \& Hart DM. Developments in steroid histochemistry. London \& New York: Academic Press, 1966.

40 Blaha GC \& Leavitt WW. The distribution of ovarian $\Delta^{5}-3 \beta$ hydroxysteroid dehydrogenase activity in the golden hamster during the estrous cycle, pregnancy, and lactation. Biology of Reproduction 19703 362-368.

41 Blaha GC \& Leavitt WW. Ovarian steroid dehydrogenase histochemistry and circulating progesterone in aged golden hamsters during the estrous cycle and pregnancy. Biology of Reproduction 197411 153-161.

42 Bjersing L. Ovarian histochemistry. In The Ovary, pp 303-388. Eds L Zuckerman \& BJ Weir. New York: Academic Press, 1977.

43 Dupont E, Zhao HF, Rheaume E, Simard J, Luu-The V, Labrie F et al. Localization of 3 beta-hydroxysteroid dehydrogenase/delta 5-delta 4 -isomerase in rat gonads and adrenal glands by immunocytochemistry and in situ hybridization. Endocrinology $1990 \mathbf{1 2 7}$ 1394-1403.

44 Juneau C, Dupont E, Luu-The V, Labrie F \& Pelletier G. Ontogenesis of 3 beta-hydroxysteroid dehydrogenase delta 5-delta 4 isomerase in the rat ovary as studied by immunocytochemistry and in situ hybridization. Biology of Reproduction $1993 \mathbf{4 8}$ $226-234$.

45 Teerds KJ \& Dorrington JH. Immunohistochemical localization of 3 beta-hydroxysteroid dehydrogenase in the rat ovary during follicular development and atresia. Biology of Reproduction $1993 \mathbf{4 9}$ 989-996.

46 Tsuri H, Yoshinaga-Hirabayashi T, Ishimura K, Osawa Y, Kominami S, Takemori S et al. Immunohistochemical studies on the localization of aromatase and 17 alpha-hydroxylase/C17-20 lyase (17 alpha-lyase) in estrous cycling and pregnant ovaries. Archives of Histology and Cytology 199255 13-20.

47 Otsuka M, Kishi H, Arai K, Watanabe G, Taya K \& Greenwald GS. Temporal changes in inhibin, steroid hormones, and steroidogenic enzymes during induced follicular atresia in the hypophysectomized cyclic hamster. Biology of Reproduction $1997 \mathbf{5 6}$ 423-429.

48 Fritz MA \& Fitz TA. The functional microscopic anatomy of the corpus luteum: the 'small cell'-'large cell' controversy. Clinical Obstetrics and Gynaecology $199134144-156$.

49 Nelson SE, McLean MP, Jayatilak PG \& Gibori G. Isolation, characterization, and culture of cell subpopulations forming the pregnant rat corpus luteum. Endocrinology $1992130954-966$.

50 Adashi EY. Endocrinology of the ovary. Human Reprodroduction $19949815-827$.

51 van Voorhis BJ. Follicular steroidogenesis. In Encyclopedia of Reproduction, vol 2, pp 389-395. Eds E Knobil \& JD Neill. San Diego: Academic Press, 1999.

52 Otsuka M, Kishi H, Arai K, Watanabe G, Taya K \& Greenwald GS. Temporal changes in inhibin, steroid hormones, and steroidogenic enzymes during induced follicular atresia in the hypophysectomized cyclic hamster. Biology of Reproduction $1997 \mathbf{5 6}$ 423-429.

53 Hsueh AJW, Adashi EY, Jones PB \& Welsh TH Jr. Hormonal regulation of the differentiation of cultured ovarian granulosa cells. Endocrine Reviews 19845 76-127.

54 Richards JS. Hormonal control of gene expression in the ovary. Endocrine Reviews $199415725-751$.

55 Billig H, Furuta I \& Hsueh AJ. Estrogens inhibit and androgens enhance granulosa cell apoptosis. Endocrinology $1993 \mathbf{1 3 3}$ 2204-2212.

56 De Pol A, Benelli A, Arletti R, Cavazzuti E, Sena P, Vaccina F et al. Influence of estrogens and oxytocin on germ cells death in the neonatal mammalian ovary. Italian Journal of Anatomy and Embryology $2001 \mathbf{1 0 6}$ (Suppl 2) 233-239.

57 Rosenfeld CS, Wagner JS, Roberts M \& Lubahn DB. Intraovarian actions of oestrogen. Reproduction 2001122 215-226.

58 Hsu SY \& Hsueh AJW. Tissue specific Bcl-2 protein partners in apoptosis: an ovarian paradigm. Physiological Reviews $2000 \mathbf{8 0}$ 593-614. 
59 Markström E, Svenson EC, Shao R, Svanberg B \& Billig H. Survival factors regulate ovarian apoptosis-dependence on follicle differentiation. Reproduction 2002123 23-30.

60 Richards JS. Perspective: The ovarian follicle - a perspective in 2001. Endocrinology 2001142 2184-2193.

61 Drummond AE \& Findlay JK. The role of estrogen in folliculogenesis. Molecular and Cellular Endocrinology 1999151 $57-64$
62 Palter SF, Tavares AB, Hourvitz A, Veldhuis JD \& Adashi EY. Are estrogens of import to primate/human ovarian folliculogenesis? Endocrine Reviews 200122 389-424.

Received 4 April 2002

Accepted 25 June 2002 